\title{
Prevalence and Determinants of Kidney Markers among Subjects with Hepatitis C Virus Infection
}

\author{
Mathurin Pierre Kowo ${ }^{1,2 *}$ (D), Sylvain Raoul Simeni Njonnou3, Murielle Sonia Mehly Ngninzeko4, \\ Firmin Ankouane Andoulo, ${ }^{1,2}$, Antonin Ndjitoyap Ndam1, Michelle Tagny Sartre ${ }^{5}$, \\ Vicky Ama Moor 2,6, Jeanne Ngongang2,4,6, François Folefack Kaze ${ }^{1,2}$ \\ ${ }^{1}$ Department of Internal Medicine and Specialty, Faculty of Medicine and Biomedical Sciences, University of Yaoundé I, Yaoundé, \\ Cameroon \\ ${ }^{2}$ Yaounde University Teaching Hospital, Yaoundé, Cameroon \\ ${ }^{3}$ Department of Internal Medicine and Specialty, Faculty of Medicine and Pharmaceutical Sciences, University of Dschang, \\ Dschang, Cameroon \\ ${ }^{4}$ Higher Institute of Health Sciences, Université des Montagnes, Bangangté, Cameroon \\ ${ }^{5}$ Medical Centre "La Cathédrale", Yaoundé, Cameroon \\ ${ }^{6}$ Department of Physiological Sciences and Biochemistry, Faculty of Medicine and Biomedical Sciences, University of Yaoundé I, \\ Yaoundé, Cameroon \\ Email: ^kowomathurinp@yahoo.fr, raoulsims@yahoo.fr,mmelhyngninzeko@icrc.org, ankouaneandoulo@yahoo.com, \\ tonindam3@yahoo.fr, mtsartre@yahoo.fr, movicky@yahoo.fr, jngongang@yahoo.fr, f_kaze@yahoo.fr
}

How to cite this paper: Kowo, M.P., Njonnou, S.R.S., Ngninzeko, M.S.M., Andoulo, F.A., Ndam, A.N., Sartre, M.T., Moor, V.A., Ngongang, J. and Kaze, F.F. (2020) Prevalence and Determinants of Kidney Markers among Subjects with Hepatitis C Virus Infection. Open Journal of Nephrology, 10, 85-101.

https://doi.org/10.4236/ojneph.2020.102010

Received: March 20, 2020

Accepted: April 18, 2020

Published: April 21, 2020

Copyright $\odot 2020$ by author(s) and Scientific Research Publishing Inc. This work is licensed under the Creative Commons Attribution-NonCommercial International License (CC BY-NC 4.0). http://creativecommons.org/licenses/by-nc/4.0/ (c) (i) (8) Open Access

\begin{abstract}
Introduction: Hepatitis $\mathrm{C}$ virus (HCV) infection is a worldwide public health problem with multisystemic involvements including kidneys. We assessed the prevalence and determinants of kidney markers among HCV infected subjects. Methods: A cross-sectional study was conducted from March to July 2017 in two referral centers in Yaoundé. Sociodemographic, clinical and paraclinical data were collected from patient's records. Renal involvement was evaluated using estimated glomerular filtration rate (eGFR) by Modification of Diet in Renal Disease's (MDRD) equation, urine dipstick and albu$\mathrm{min} /$ creatinine ratio (ACR). An eGFR $<60$ and between $60-89 \mathrm{~mL} / \mathrm{min} / 1.73$ $\mathrm{m}^{2}$ was defined as low and reduced respectively. Albuminuria was defined by an ACR $>30 \mathrm{mg} / \mathrm{g}$ and divided into A1 (<30 mg/g), A2 $(30-300 \mathrm{mg} / \mathrm{g})$ and A3 (>300 mg/g). Results: We included 65 (41.5\% males) HCV infected patients with a mean age of $56.8 \pm 10.5$ years. HCV infection was diagnosed for more than 5 years in $54(83.1 \%)$ patients. HCV viral load and genotype were available in $40(61.5 \%)$ patients; viral load was high $(>5.9 \mathrm{logs} / \mathrm{mL})$ in 20 (50\%) of them and genotypes 4 (40\%), 1 (32.5\%) and $2(27.5 \%)$ were found in this population. The mean eGFR was $112.9 \pm 31.9 \mathrm{~mL} / \mathrm{min} / 1.73 \mathrm{~m}^{2}$ with 14
\end{abstract}


(21.5\%) and $4(6.2 \%)$ patients having reduced and low eGFR respectively. Albuminuria (80\%), leukocyturia (24.6\%) and hematuria (4.6\%) were the observed dipstick abnormalities. Median albuminuria (IQR) was 542.4 (238.7 961.5) $\mathrm{mg} / \mathrm{g}$, with 7 (11\%), 12 (18\%) and 46 (71\%) patients in A1, A2 and A3 respectively. Reduced/low eGFR and albuminuria were observed in 58 (89.2\%) patients while low eGFR and albuminuria were found in 55 (84.6\%) patients. Advanced age, female gender, HCV genotype 1 and 4, and albuminuria (all $\mathrm{p}<0.03$ ) were associated with eGFR reduction. Conclusion: Renal abnormalities are common in HCV infected patients leading by proteinuria and decreased eGFR. Known risk factors of kidney diseases, HCV genotype 1 and 4 and albuminuria were associated with eGFR reduction in our setting.

\section{Keywords}

Hepatitis C Virus, Chronic Kidney Disease, Prevalence, Sub-Saharan Africa

\section{Introduction}

Chronic viral hepatitis $\mathrm{C}$ (CVHC) predisposes to liver fibrosis and is a major cause of liver-related mortality and morbidity [1] [2]. With a global prevalence of 3\% (71 million persons infected), CVHC infection is a major public health problem worldwide [1] [3]. Its prevalence ranges from $0.4 \%$ in Western Europe to more than 9\% in Central Africa [3] [4]. Cameroon is one of the most affected countries, with a nation-wide prevalence of $6.5 \%$ [5]. This prevalence varies according to regional and temporal disparities ranging from 13\% among Pygmies and Bantus in South Cameroon to 21.1\% in the East region [5] [6].

Morbi-mortality of hepatitis C virus (HCV) infection is mainly related to cirrhosis and hepatocellular carcinoma [7]. Despite the HCV hepatotrophicity, it can affect other organs, leading to manifestations such as autoimmune, metabolic, renal, cardiovascular, central nervous system, and lymphoproliferative disorders [8] [9] [10] [11]. Those extrahepatic manifestations are rarely in the foreground but can reveal the disease, may be severe and require urgent management. Recent studies show a variation of extrahepatic manifestations ranging from $1.76 \%$ for ischemic stroke to $50 \%$ for neurocognitive changes, porphyria cutanea tarda and cutaneous vasculitis [9]. The renal manifestations of HCV infection are common and contribute to worsening prognosis as well as the burden of the disease; they are mainly glomerular including membranoproliferative glomerulonephritis, membranous nephropathy and cryoglobulinemia [10] [12]. They lead to chronic kidney disease (CKD) which progresses to end-stage kidney disease [13] [14] [15] [16] [17].

If renal manifestations of HCV infection have been widely assessed in Western countries, these have been poorly investigated in Africa [18] [19] [20]. A recent study in Cameroon found an anti-HCV prevalence of $19.2 \%$ among patients on maintenance hemodialysis (MHD) [21]. With the availability of direct-acting 
antiviral agents (DAAA), it was therefore important for us to assess the prevalence of renal manifestations of HCV infection and identify associated risk factors. The early diagnosis will help to introduce nephroprotection measures within such a population.

\section{Methods}

Study design and setting: This cross-sectional study was carried out in two therapeutic centers for hepatitis management in Yaounde (Yaounde University Teaching Hospital and Medical Centre "La Cathédrale"). Yaounde University Teaching Hospital is a tertiary hospital while Medical Centre "La Cathédrale" is a private medical institution with a high technology platform; all in Yaounde, the capital city of Cameroon.

Study population: Patients seen in outpatient consultation and hospitalization ward with the diagnosis of HCV infection were recruited. Patients followed up, but not seen at outpatient consultation were invited through phone calls to participate to the study. Detection of HCV antibodies was done using a rapid diagnostic test and those who tested positive had a confirmatory ELISA test.

Variables and Measurements: All consenting HCV-infected subjects above 18 years, naïve to treatment were included. Patients with conditions that may lead to confusion at the urine test such as hypertension, diabetes, hepatitis B virus infection, HIV infection, systemic lupus, renal lithiasis or urinary tract infection, were excluded. Sociodemographic characteristics (age, gender, profession, alcohol consumption, smoking), clinical data (weight, height, signs of hepatocellular failure and/or portal hypertension), biological (serum and urinary creatinine, urine dipstick, 24 hours albuminuria) and virological parameters (HCV-viral load and genotype) were collected. Height (in m) was measured using a wooden platform and a height rule. Body mass index (BMI) was calculated as weight $(\mathrm{kg}) /$ height $(\mathrm{m}) \times$ height $(\mathrm{m})$.

Quantitative determination of HCV RNA and the genotyping were requested for each new patient. For followed up patients, these pieces of information were obtained from their files. Fibroscan ${ }^{\circledR}$ (Echosens, Paris, France), a noninvasive marker of fibrosis, was used and converted to the METAVIR score to categorize fibrosis in chronic hepatitis $\mathrm{C}$ according to a 5-stages classification: F0 (no fibrosis), F1 (portal and periportal fibrosis without septa), F2 (portal and periportal fibrosis with rare septa), F3 (numerous septa without cirrhosis), and F4 (cirrhosis). The selection process is summarized in Figure 1.

\section{Laboratory testing}

For each patient, blood and urinary samples were collected. Urine dipstick tests were conducted with CombiScreen ${ }^{\circ}$ 7SL PLUS 7 test strips (Analyticon Biotechnologies AG, D-35,104 Lichentenfeis, Germany). Urinary pH, specific gravity and glucose were not taken into consideration for the purpose of the study.

Serum and urinary creatinine were conducted using a kinetic method called "Jaffé reaction" (with CYPRESS reagents, CYPRESS Diagnostics, Hulshout, 


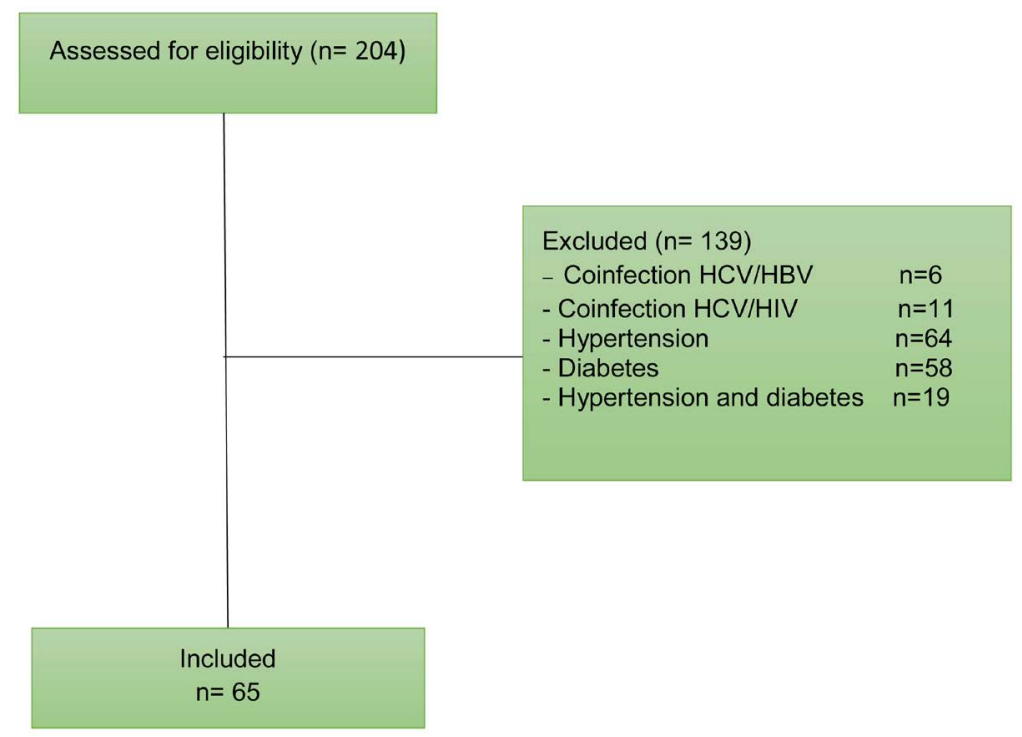

Figure 1. Patient flow chart.

Belgium). Albuminuria dosage was performed using a spectrophotometric method. Glomerular filtration rate (GFR) was estimated by The Modification of Diet in Renal Disease (MDRD) equation [15]. A urine dipstick test was conducted for evaluating albuminuria, hematuria and leukocyturia. 24 hours albuminuria was estimated using urine albumin/creatinine ratio (ACR) from the urine spot.

\section{Definitions:}

Obesity was defined as a body mass index (BMI) $\geq 30 \mathrm{~kg} / \mathrm{m}^{2}$, and overweight was defined as a BMI between 25 and $29.9 \mathrm{~kg} / \mathrm{m}^{2}$. Excessive alcohol consumption was considered for a consumption $>30 \mathrm{~g} /$ day for women and $40 \mathrm{~g} /$ day for men or more than 10 ( 5 for women) local beers per week. The METAVIR score also categorized activity according to a 4-grade classification: A0 (no activity), A1 (minimal activity), A2 (moderate activity), and A3 (severe activity) [22]. GFR (in $\mathrm{mL} / \mathrm{min}$ per $1.73 \mathrm{~m}^{2}$ ) was divided into G1 (>90), G2 (60 - 89), G3 (30 - 59) G4 (15 - 29) and G5 (<15). For this study, an eGFR $<60 \mathrm{~mL} / \mathrm{min}$ per $1.73 \mathrm{~m}^{2}$ was considered as low while between $60-89 \mathrm{~mL} / \mathrm{min}$ per $1.73 \mathrm{~m}^{2}$ was defined as reduced. Raised creatinine was considered for levels $>1.3 \mathrm{mg} / \mathrm{dL}$. Albuminuria was defined by ACR $\geq 30 \mathrm{mg} / \mathrm{g}$. It was divided into A1 (ACR $<30 \mathrm{mg} / \mathrm{g}$ ), A2 (ACR $(30-300 \mathrm{mg} / \mathrm{g}$ ) and A3 (ACR $>300 \mathrm{mg} / \mathrm{g}$ ). The diagnosis of urine dipstick abnormalities was based on at least $1+$ confirmed by a second test two weeks later. An abnormal GPT level was defined as values greater than $35 \mathrm{IU} / \mathrm{L}$. HCV viral load was considered as high if $>800,000 \mathrm{IU} / \mathrm{mL}$ (5.9 logs $/ \mathrm{mL}$ ) [23].

Sample size and Statistical analysis: A consecutive sample of all eligible cases was considered for this study. Data were analyzed using Statistical Package for Social Sciences (SSPS Inc, Chicago, Illinois, USA) V.20.0 and EPI-INFO V.3.5 software. Discrete variables were presented as counts and percentages, and continuous variables as mean (standard deviation) or median (IQR). The Chi-square test was used, Student $\mathrm{t}$-test, and ANOVA where appropriate. 


\section{Results}

\section{Characteristics of the study population}

We included 65 (41.5\% males) HCV-infected patients, naïve to treatment. Patients' mean age was $56.8 \pm 10.5$ years with $30(46.2 \%)$ above 60 years old. The mean BMI was $27.1 \pm 4.2 \mathrm{Kg} / \mathrm{m}^{2}$ with overweight and obesity found in 35 (53.8\%) and 15 (23.1\%) patients respectively. Regular consumption of nephrotoxics was found in $35(53.8 \%)$ patients. At-risk alcohol consumption was observed in 4 (6.2\%) patients. There were 54 (83.1\%) patients diagnosed with HCV infection for more than 5 years.

HCV viral load was performed in $40(61.5 \%)$ patients with a mean of was 6.3 \pm 3.5 logs and 20 (50\%) patients had a viral load greater than 5.9 logs. Genotype: 4 (40\%), 1 (32.5\%) and $2(27.5 \%)$ were found in this population. Liver fibrosis was evaluated in 50 patients with the following stage F4 (32\%), F3 (10\%), F2 (18\%), F1 (22\%) and F0 (18\%). The mean GPT was $37.9 \pm 24 \mathrm{U} / \mathrm{L}$ and was increased in $24(36.9 \%)$ patients. Table 1 reports the clinicobiological characteristics of the study population.

\section{Kidney function and urine profile}

Median albuminuria (IQR) was $542.4(238.7$ - 961.5) $\mathrm{mg} / \mathrm{g}$, with 7 (11\%), 12 (18\%) and 46 (71\%) patients classified in A1, A2 and A3 categories respectively. Association of reduced/low eGFR and albuminuria was observed in 58 (89.2\%) patients while low eGFR associated with albuminuria was found in 55 (84.6\%) patients (Figure 2).

The mean serum creatinine was $1.2 \pm 0.3 \mathrm{mg} / \mathrm{dL}$ with 16 (24.6\%) having raised serum creatinine. The mean eGFR was $112.9 \pm 31.9 \mathrm{~mL} / \mathrm{min} / 1.73 \mathrm{~m}^{2}$ with 14 (21.5\%) and $4(6.2 \%)$ patients having reduced and low eGFR respectively. Albuminuria (80\%), leukocyturia (24.6\%) and hematuria (4.6\%) were dipstick abnormalities recorded for the purpose of the study. These abnormalities were also

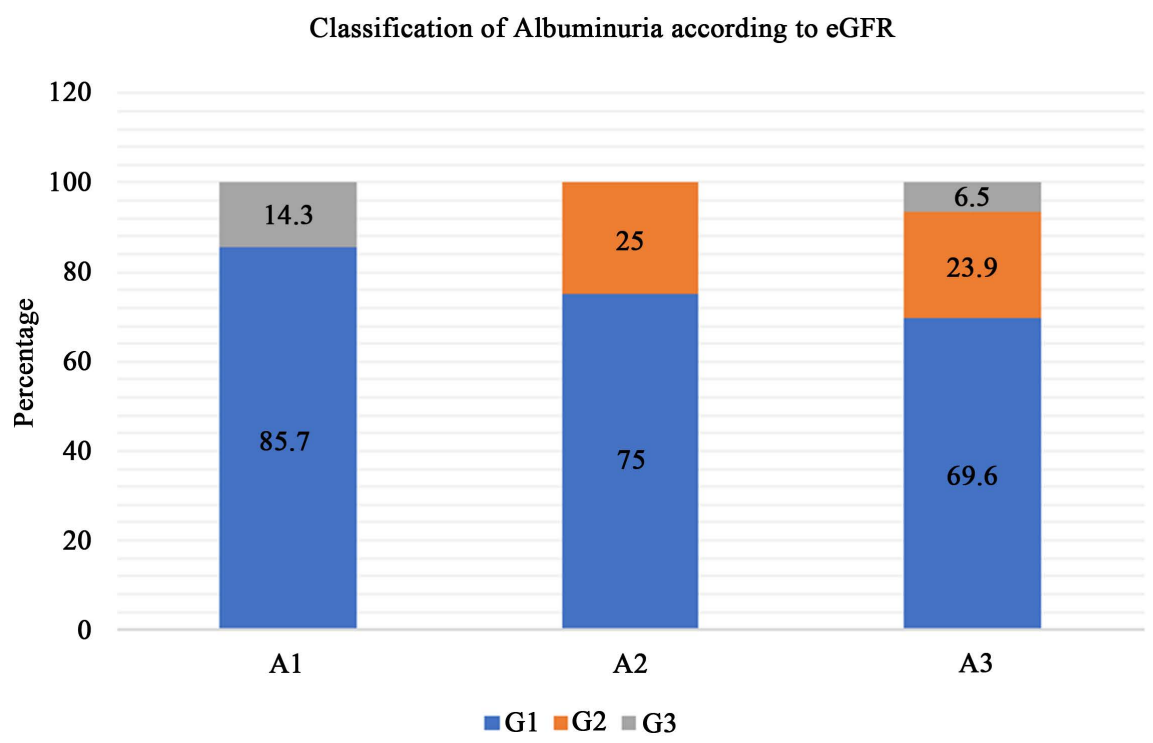

Figure 2. Classification of albuminuria according eGFR. 
Table 1. Clinicobiological profile of the study population.

\begin{tabular}{|c|c|c|}
\hline Variables & Frequency (n) & Percentage (\%) \\
\hline \multicolumn{3}{|l|}{ Gender } \\
\hline Male & 27 & 41.5 \\
\hline Female & 38 & 58.5 \\
\hline \multicolumn{3}{|l|}{ Age group } \\
\hline $20-39$ & 7 & 10.8 \\
\hline $40-59$ & 28 & 43.1 \\
\hline$\geq 60$ & 30 & 46.1 \\
\hline \multicolumn{3}{|l|}{ Duration of $\mathrm{HCV}$ infection (in years) } \\
\hline $1-5$ & 54 & 83.1 \\
\hline $6-10$ & 8 & 12.3 \\
\hline $11-20$ & 3 & 4.6 \\
\hline \multicolumn{3}{|l|}{ Drug consumption } \\
\hline Traditional medicine & 12 & 6.1 \\
\hline Modern medicine & 22 & 18.5 \\
\hline Modern and traditional medicine & 4 & 33.8 \\
\hline None & 27 & 41.6 \\
\hline \multicolumn{3}{|l|}{ Alcohol consumption } \\
\hline Yes & 7 & 10.8 \\
\hline At-risk & 4 & 6.1 \\
\hline No & 58 & 89.2 \\
\hline \multicolumn{3}{|l|}{ Body mass index } \\
\hline Normal & 27 & 41.5 \\
\hline Overweight & 23 & 35.4 \\
\hline Obesity & 15 & 23.1 \\
\hline \multicolumn{3}{|l|}{ Genotype $(n=42)$} \\
\hline 1 & 13 & 20.9 \\
\hline 2 & 11 & 26.1 \\
\hline 3 & 2 & 4.8 \\
\hline 4 & 16 & 38.1 \\
\hline \multicolumn{3}{|l|}{ Fibrosis staging $(n=50)$} \\
\hline F0 & 9 & 18 \\
\hline $\mathrm{F} 1$ & 11 & 22 \\
\hline $\mathrm{F} 2$ & 9 & 18 \\
\hline F3 & 5 & 10 \\
\hline $\mathrm{F} 4$ & 16 & 32 \\
\hline
\end{tabular}




\section{Continued}

\begin{tabular}{ccc}
\hline Dipstick profile & & \\
Isolated albuminuria & 35 & 53.8 \\
Isolated leucocyturia & 0 & 0 \\
Isolated hematuria & 0 & 0 \\
Albuminuria + Leukocyturia & 16 & 24.6 \\
Albuminuria + hematuria & 3 & 4.6 \\
Albuminuria + Leukocyturia + hematuria & 2 & 3.1 \\
Albuminuria categories & & \\
A1 & 7 & 10.7 \\
A2 A3 & 12 & 18.5 \\
Cytolysis & 46 & 70.8 \\
Increased ALAT & & 36.9 \\
Increased ASAT & 24 & 58.5 \\
Increased creatinine & 38 & 24.6 \\
Reduced eGFR & 16 & 6.1
\end{tabular}

associated to each other with albuminuria-leukocyturia in $16(24.6 \%)$ patients, albuminuria-hematuria in 3 (4.6\%) patients and albuminuria-hematuria-leukocyturia in $2(3.1 \%)$ patients.

\section{Determinants of renal markers}

We observed that advanced age $(\mathrm{p}=0.018)$, female gender $(\mathrm{p}<0.001)$, HCV genotype 1 and $4(\mathrm{p}=0.003)$ and albuminuria $(\mathrm{p}=0.03)$ were associated with low/reduce eGFR (Table 2). There was no factor associated with albuminuria (all p > 0.05) (Table 3).

\section{Discussion}

This cross-sectional study, assessing the prevalence and associated factors of renal markers among HCV-infected patients in a sub-Saharan African (SSA) setting, revealed that kidney abnormalities are common, leading by proteinuria (89.2\%) and reduced/low eGFR (27.7\%). Advanced age, female gender, HCV genotype 1 and 4, and albuminuria were associated with eGFR reduction. This study represents to our knowledge, the first published analysis of renal involvement of HCV infection in SSA.

The female predominance of HCV antibodies in this population (58.4\%) was similar to reports done by other authors [24] [25]. Patients' mean age was high (56.8 \pm 10.5 years), similar to that reported by Kowo et al. and Denniston et al. [6] [26]. It might be related to the age at the contamination time probably during the mass vaccination campaign before virus discovery. However, the discovery of the infection was less than 5 years old in most (83.1\%) of these patients. 
Table 2. Factors associated with glomerular filtration rate levels.

\begin{tabular}{|c|c|c|}
\hline Variables & Mean eGFR $\left(\mathrm{ml} / \mathrm{min} / 1.73 \mathrm{~m}^{2}\right)$ & $\mathrm{p}$ value \\
\hline \multicolumn{3}{|l|}{ Age group } \\
\hline $20-39$ & 141 & \multirow{3}{*}{0.018} \\
\hline $40-59$ & 115.2 & \\
\hline$\geq 60$ & 104.2 & \\
\hline \multicolumn{3}{|l|}{ Gender } \\
\hline Male & 129.5 & \multirow{2}{*}{$<0.001$} \\
\hline Female & 101.2 & \\
\hline \multicolumn{3}{|c|}{ Duration of $\mathrm{HCv}$ infection (in years) } \\
\hline $1-5$ & 114.6 & \multirow{3}{*}{0.565} \\
\hline $6-10$ & 107.7 & \\
\hline $11-20$ & 96 & \\
\hline \multicolumn{3}{|c|}{ Traditional Medicine } \\
\hline Yes & 118.5 & \multirow{2}{*}{0.448} \\
\hline No & 111.3 & \\
\hline \multicolumn{3}{|c|}{ Modern Medicine } \\
\hline Yes & 105.8 & \multirow{2}{*}{0.168} \\
\hline No & 117.1 & \\
\hline \multicolumn{3}{|c|}{ Alcohol consumption } \\
\hline Yes & 128.3 & \multirow{2}{*}{0.094} \\
\hline No & 111.1 & \\
\hline \multicolumn{3}{|c|}{ Body mass index } \\
\hline Normal & 114 & \multirow{2}{*}{0.815} \\
\hline Increased & 112.1 & \\
\hline \multicolumn{3}{|c|}{ HCV viral load } \\
\hline Increased & 120.3 & \multirow{2}{*}{0.386} \\
\hline Low & 112.8 & \\
\hline \multicolumn{3}{|c|}{ Fibrosis staging } \\
\hline F0 & 119.6 & \multirow{5}{*}{0.979} \\
\hline $\mathrm{F} 1$ & 120.4 & \\
\hline $\mathrm{F} 2$ & 113.6 & \\
\hline F3 & 115.6 & \\
\hline F4 & 112.8 & \\
\hline \multicolumn{3}{|l|}{ Genotype } \\
\hline 1 & 110.1 & \multirow{4}{*}{0.003} \\
\hline 2 & 137.6 & \\
\hline 3 & 170 & \\
\hline 4 & 107.9 & \\
\hline
\end{tabular}




\section{Continued}

\section{ALAT}

Normal

111

Increased

116.1

0.541

ASAT

Normal

115.1

Increased

111.3

0.640

Dipstick albuminuria

$$
\text { Yes }
$$

108.6

No

130

0.030

Dipstick leukocyturia

Yes

117.8

No

111.3

0.480

Dipstick hematuria

Yes

109.6

No

113.1

0.858

Albuminuria categories

A1

129.1

A2

116.8

0.286

A3

109.4

Table 3. Factors associated with albuminuria.

\begin{tabular}{|c|c|c|}
\hline Variables & Albuminuria & $\mathrm{p}$ value \\
\hline \multicolumn{3}{|l|}{ Age group } \\
\hline $20-39$ & 841.3 & \multirow{3}{*}{0.050} \\
\hline $40-59$ & 625.6 & \\
\hline$\geq 60$ & 1112.2 & \\
\hline \multicolumn{3}{|l|}{ Gender } \\
\hline Male & 817.8 & \multirow[b]{2}{*}{0.915} \\
\hline Female & 912.9 & \\
\hline \multicolumn{3}{|c|}{ Duration of HCV infection (in years) } \\
\hline $1-5$ & 709.9 & \multirow{3}{*}{0.127} \\
\hline $6-10$ & 1510.7 & \\
\hline $11-20$ & 2116.6 & \\
\hline \multicolumn{3}{|c|}{ Traditional Medicine } \\
\hline Yes & 851.1 & \multirow{2}{*}{0.937} \\
\hline No & 880.1 & \\
\hline
\end{tabular}


Continued

Modern Medicine

Yes

1098.1

No

741.8

0.376

Alcohol consumption

Yes

No

Body mass index

Normal

Increased

HCV viral load

Increased

Low

Fibrosis staging

F0

F1

F2

F3

F4

Genotype

1

2

3

4

ALAT

Normal

Increased

ASAT

Normal

Increased

Dipstick leukocyturia

Yes

No

Dipstick hematuria

Yes

No
610.9

905.1

0.557

868.8

876.6

0.980

805.5

795.4

410.3

868.6

468.2

0.180

1750.7

1072

585.5

895.8

628

666

683.3

1198.2

0.462

639.4

1039.6

0.196

1385.1

706.3

0.345

2685.5

785.7

0.999 
The recent introduction of information and screening campaigns could explain this result. Unlike Caucasians, our patients had low alcohol consumption and smoking [27]. The mean BMI of this population was similar to Naga et al. findings [28]. This increased BMI promotes liver fibrosis and carcinogenesis, hence the need for lifestyle modifications [29] [30]. Pre-therapeutic workup shows moderate to severe fibrosis among the study population. This is probably due to long and slow evolution of the disease and late diagnosis, usually with complications, in Africa [31]. Only two over three patients performed HCV viral load, due to the high cost of this exam. Half of them had a high viral load, similar to Sonderup et al. reports [32]. Genotype testing revealed a type 4 predominance similar to Njouom et al. in south-Cameroon and Ndong-Atome et al. in Gabon [33] [34]. Although genotypes 1 and 4 predominate in SSA, genotype 4 is most frequent in central Africa [31] [32].

The mean eGFR was $112.9 \pm 31.9 \mathrm{ml} / \mathrm{min} / 1.73 \mathrm{~m}^{2}$. Our findings were close to those from Saddadi et al. and Tsui et al. respectively in Iran and the United States of America (USA) [27] [35]. Reduced eGFR was found in 4 (6.2\%) patients. This prevalence was higher than those from Saddadi et al. (0.6\%) and Tsui et al. (2\%) [27] [35]. This discrepancy could be due to the difference in population and the late diagnosis of the disease. A high prevalence of albuminuria (89.2\%) was found in this population contrasting with the $4 \%$ and $8.3 \%$ found by Saddadi et al. and Huang et al. respectively [35] [36]. An explanation of this difference could be the elevated albuminuria threshold used by Saddadi et al. (500 $\mathrm{mg} / 24 \mathrm{~h}$ ) and the different methods for determining albuminuria. Otherwise, moderate albuminuria prevalence was similar to Liangpunsakul et al. findings [29]. However, severe albuminuria prevalence in our population was high. This discrepancy could be explained by the disease age (high in Africa's population) and probably increased by the intake of nephrotoxic drugs. Proteinuria and hematuria found at urine dipstick could reinforce the hypothesis of HCV-related glomerular disease, mainly membranoproliferative glomerulonephritis and membranous nephropathy [35] [37] [38]. Leukocyturia, on the contrary, seems to correlate with the interstitial involvement of HCV infection [39].

Advanced age, female gender, HCV genotype and albuminuria (all $\mathrm{p}<0.03$ ) were associated with eGFR reduction in univariate analysis. Patients with type 1 and 4 genotypes seemed to have a reduced eGFR as compared to others, but the small study population reduces our capacity to make significant associations. Tsui et al. found no association between age and renal manifestation, but Liangpunsakul et al. showed an association between albuminuria, advanced age and the black race in patients with HCV infection [27] [29]. A confounding factor could be the drug intake, responsible for renal toxicity, which was found in more than half of patients. Similarly to Iseki et al., albuminuria was associated with reduced eGFR, suggesting the role of proteinuria in the progression of CKD [40]. However, no association with albuminuria was observed.

This study should be interpreted in light of some limitations. Our study pop- 
ulation was small compared to other studies on this subject. We excluded many patients with confounding factors for proteinuria to avoid bias. Another limitation was biological and anatomopathological exams. Urine sediment, which is more reliable for hematuria and leukocyturia, was not performed. Due to limited financial issues, just a urine dipstick was realized. No kidney biopsy was performed in this population.

\section{Conclusion}

This study is the first of its type carried out in Cameroon. The prevalence of renal manifestations of HCV infection is high, led by proteinuria and reduced/low eGFR. Advanced age, female gender, HCV genotype 1 and 4, and albuminuria were associated with eGFR reduction. A regular follow-up of these patients with eGFR determination and urinalysis is necessary for the early diagnosis of renal manifestations and the implementation of nephroprotective measures.

\section{Acknowledgements}

We thank all the staff of the Gastroenterology and laboratory units at of the Yaounde University Teaching Hospital and all the staff of the Medical Centre "La Cathédrale".

\section{Availability of Data and Materials}

The dataset analyzed during this study is not publicly available due to individual privacy issues. It could be available from the corresponding author on a reasonable request.

\section{Authors' Contribution}

Conception and Design: JN, MSMN, MPK, FJKF. Data collection: MSMN, MPK, FJKF, MTS. Administrative support: MTS, MPK, FJKF, JN, FAA, MTS. Data analysis and Interpretation: MSMN, MPK, SRSN, ANN. Drafting of the manuscript: SRSN, MSMN, MPK. Reviewing Manuscript: MTS, FJKF, VAM. All the authors read and approved the final draft for publication.

\section{Funding}

No funding was received for this study.

\section{Conflicts of Interest}

The authors declare that they have no competing interests.

\section{Ethical Consideration}

This work was approved by the institutional review board of the Higher Institute of Health Sciences, Université des Montagnes, Bangangte, Cameroon (registration number 2014/82/UdM/PR/CAB/CIE). Administrative authorization from the Yaounde University Teaching Hospital, Medical Centre "La Cathédrale" was 
obtained. This work was carried out in accordance with the declarations of Helsinki [41]. All ethical rules involving research on disadvantaged groups such as prisoners have been respected [42]. Patients were informed and a signed consent forms was collected from each participant who was equally free to attend the study without any outside constraint. This work is reported in compliance with the STROBE checklist.

\section{References}

[1] World Health Organization (2017) Global Hepatitis Programme. Global Hepatitis Report. http://apps.who.int/iris/bitstream/10665/255016/1/9789241565455-eng.pdf?ua=1

[2] Hallager, S., Ladelund, S., Christensen, P.B., Kjær, M., Thorup Roege, B., Grønbæk, K.E., et al. (2017) Liver-Related Morbidity and Mortality in Patients with Chronic Hepatitis C and Cirrhosis with and without Sustained Virologic Response. Clinical Epidemiology, 9, 501-516. https://doi.org/10.2147/CLEP.S132072

[3] Esteban, J.I., Sauleda, S. and Quer, J. (2008) The Changing Epidemiology of Hepatitis C Virus Infection in Europe. Journal of Hepatology, 48, 148-162.

https://doi.org/10.1016/j.jhep.2007.07.033

[4] El-Ghitany, E.M. and Farghaly, A.G. (2019) Geospatial Epidemiology of Hepatitis C Infection in Egypt 2017 by Governorate. Heliyon, 5, 1-8. https://doi.org/10.1016/j.heliyon.2019.e02249

[5] Bigna, J.J., Amougou, M.A., Asangbeh, S.L., Kenne, A.M. and Nansseu, J.R. (2017) Seroprevalence of Hepatitis C Virus Infection in Cameroon: A Systematic Review and Meta-Analysis. BMJ Open, 7, e015748. https://doi.org/10.1136/bmjopen-2016-015748

[6] Kowo, M.P., Goubau, P., Ndam, E.C., Njoya, O., Sasaki, S., Seghers, V., et al. (1995) Prevalence of Hepatitis C Virus and Other Blood-Borne Viruses in Pygmies and Neighbouring Bantus in Southern Cameroon. Transactions of the Royal Society of Tropical Medicine and Hygiene, 89, 484-486. https://doi.org/10.1016/0035-9203(95)90076-4

[7] Maasoumy, B. and Wedemeyer, H. (2012) Natural History of Acute and Chronic Hepatitis C. Best Practice \& Research Clinical Gastroenterology, 26, 401-412. https://doi.org/10.1016/j.bpg.2012.09.009

[8] Cacoub, P., Poynard, T., Ghillani, P., Charlotte, F., Olivi, M., Piette, J.C., et al. (1999) Extrahepatic Manifestations of Chronic Hepatitis C. MULTIVIRC Group. Multidepartment Virus C. Arthritis \& Rheumatology, 42, 2204-2212. https://doi.org/10.1002/1529-0131(199910)42:10<2204::AID-ANR24>3.0.CO;2-D

[9] Sherman, A.C. and Sherman, K.E. (2015) Extrahepatic Manifestations of Hepatitis C Infection: Navigating CHASM. Current HIVI AIDS Reports, 12, 353-361. https://doi.org/10.1007/s11904-015-0274-8

[10] Cacoub, P., Comarmond, C., Domont, F., Savey, L., Desbois, A.C. and Saadoun, D. (2016) Extrahepatic Manifestations of Chronic Hepatitis C Virus Infection. Therapeutic Advances in Infectious Disease, 3, 3-14. https://doi.org/10.1177/2049936115585942

[11] Cacoub, P., Gragnani, L., Comarmond, C. and Zignego, A.L. (2014) Extrahepatic Manifestations of Chronic Hepatitis C Virus Infection. Digestive and Liver Disease, 46, S165-S173. https://doi.org/10.1016/j.dld.2014.10.005

[12] Tarantino, A., Campise, M., Banfi, G., Confalonieri, R., Bucci, A., Montoli, A., et al. 
(1995) Long-Term Predictors of Survival in Essential Mixed Cryoglobulinemic Glomerulonephritis. Kidney International, 47, 618-623. https://doi.org/10.1038/ki.1995.78

[13] Levey, A.S., de Jong, P.E., Coresh, J., El Nahas, M., Astor, B.C., Matsushita, K., et al. (2011) The Definition, Classification, and Prognosis of Chronic Kidney Disease: A KDIGO Controversies Conference Report. Kidney International, 80, 17-28. https://doi.org/10.1038/ki.2010.483

[14] Kidney Disease: Improving Global Outcomes (KDIGO) Hepatitis C Work Group KDIGO (2018) Clinical Practice Guideline for the Prevention, Diagnosis, Evaluation, and Treatment of Hepatitis C in Chronic Kidney Disease. Kidney International Supplements, 8, 91-165. https://doi.org/10.1016/j.kisu.2018.06.001

[15] Levey, A.S., Coresh, J., Greene, T., Stevens, L.A. Zhang, Y., Hendriksen, S., et al. (2006) Using Standardized Serum Creatinine Values in the Modification of Diet in Renal Disease Study Equation for Estimating Glomerular Filtration Rate. Annals of Internal Medicine, 145, 247. https://doi.org/10.7326/0003-4819-145-4-200608150-00004

[16] Levey, A.S., Stevens, L.A., Schmid, C.H., Zhang, Y., Castro, A.F., Feldman, H.I., et al. (2009) A New Equation to Estimate Glomerular Filtration Rate. Annals of Internal Medicine, 150, 604. https://doi.org/10.7326/0003-4819-150-9-200905050-00006

[17] Goel, A., Bhadauria, D.S. and Aggarwal, R. (2018) Hepatitis C Virus Infection and Chronic Renal Disease: A Review. Indian Journal of Gastroenterology, 37, 492-503. https://doi.org/10.1007/s12664-018-0920-3

[18] Sabry, A., El-Agroudy, A., Sheashaa, H., El-Husseini, A., Taha, N.M., Elbaz, M., et al. (2005) Histological Characterization of HCV-Associated Glomerulopathy in Egyptian Patients. International Urology and Nephrology, 37, 355-361. https://doi.org/10.1007/s11255-004-4096-7

[19] Naicker, S., Fabian, J., Naidoo, S., Wadee, S., Paget, G. and Goetsch, S. (2007) Infection and Glomerulonephritis. Seminars in Immunopathology, 29, 397-414. https://doi.org/10.1007/s00281-007-0088-x

[20] Mohammed, R.H.A., ElMakhzangy, H.I., Gamal, A., Mekky, F., El Kassas, M., Mohammed, N., et al. (2010) Prevalence of Rheumatologic Manifestations of Chronic Hepatitis C Virus Infection among Egyptians. Clinical Rheumatology, 29, 1373-1380. https://doi.org/10.1007/s10067-010-1463-x

[21] Luma, H.N., Halle, M.P., Fiacre, S.A., Azingala, F., Kamdem, F., Donfack-Sontsa, O., et al. (2017) Seroprevalence of Human Immunodeficiency Virus, Hepatitis B and C Viruses among Haemodialysis Patients in Two Newly Opened Centres in Cameroon. Pan African Medical Journal, 27, 1-10.

https://doi.org/10.11604/pamj.2017.27.235.13121

[22] Poynard, T., Bedossa, P. and Opolon, P. (1997) Natural History of Liver Fibrosis Progression in Patients with Chronic Hepatitis C. The OBSVIRC, METAVIR, CLINIVIR, and DOSVIRC Groups. The Lancet (London, England), 349, 825-832. https://doi.org/10.1016/S0140-6736(96)07642-8

[23] European Association for the Study of the Liver (2011) EASL Clinical Practice Guidelines: Management of Hepatitis C Virus Infection. Journal of Hepatology, 55, 245-264. https://doi.org/10.1016/j.jhep.2011.02.023

[24] Meffre, C., Le Strat, Y., Delarocque-Astagneau, E., Dubois, F., Antona, D., Lemasson, J.-M., et al. (2010) Prevalence of Hepatitis B and Hepatitis C Virus Infections in France in 2004: Social Factors Are Important Predictors after Adjusting for 
Known Risk Factors. Journal of Medical Virology, 82, 546-555. https://doi.org/10.1002/jmv.21734

[25] Desenclos, J.C. (2000) Epidemiology of Hepatitis C. La Revue du Praticien, 50, 1066-1070.

[26] Denniston, M.M., Jiles, R.B., Drobeniuc, J., Klevens, R.M., Ward, J.W., McQuillan, G.M., et al. (2014) Chronic Hepatitis C Virus Infection in the United States, National Health and Nutrition Examination Survey 2003 to 2010. Annals of Internal Medicine, 160, 293-300. https://doi.org/10.7326/M13-1133

[27] Tsui, J.I., Vittinghoff, E., Shlipak, M.G. and O’Hare, A.M. (2006) Relationship between Hepatitis $\mathrm{C}$ and Chronic Kidney Disease: Results from the Third National Health and Nutrition Examination Survey. Journal of the American Society of Nephrology: JASN, 17, 1168-1174. https://doi.org/10.1681/ASN.2005091006

[28] Naga, M. (2015) Low-Density Lipoprotein Receptor Genetic Polymorphism in Chronic Hepatitis C Virus Egyptian Patients Affects Treatment Response. World Journal of Gastroenterology, 21, 11141-11151. https://doi.org/10.3748/wjg.v21.i39.11141

[29] Liangpunsakul, S. and Chalasani, N. (2005) Relationship between Hepatitis C and Microalbuminuria: Results from the NHANES III. Kidney International, 67, 285-290. https://doi.org/10.1111/j.1523-1755.2005.00080.x

[30] Akiyama, T., Mizuta, T., Kawazoe, S., Eguchi, Y., Kawaguchi, Y., Takahashi, H., et al. (2011) Body Mass Index Is Associated with Age-at-Onset of HCV-Infected Hepatocellular Carcinoma Patients. World Journal of Gastroenterology, 17, 914-921. https://doi.org/10.3748/wjg.v17.i7.914

[31] Karoney, M.J. and Siika, A.M. (2013) Hepatitis C Virus (HCV) Infection in Africa: A Review. Pan African Medical Journal, 14, 44. https://doi.org/10.11604/pamj.2013.14.44.2199

[32] Sonderup, M.W., Afihene, M., Ally, R., Apica, B., Awuku, Y., Cunha, L., et al. (2017) Hepatitis C in Sub-Saharan Africa: The Current Status and Recommendations for Achieving Elimination by 2030. The Lancet Gastroenterology and Hepatology, 2, 910-919. https://doi.org/10.1016/S2468-1253(17)30249-2

[33] Njouom, R., Frost, E., Deslandes, S., Mamadou-Yaya, F., Labbé, A.-C., Pouillot, R., et al. (2009) Predominance of Hepatitis C Virus Genotype 4 Infection and Rapid Transmission between 1935 and 1965 in the Central African Republic. Journal of General Virology, 90, 2452-2456. https://doi.org/10.1099/vir.0.011981-0

[34] Ndong-Atome, G.R., Makuwa, M., Ouwe-Missi-Oukem-Boyer, O., Pybus, O.G., Branger, M., Le Hello, S., et al. (2008) High Prevalence of Hepatitis C Virus Infection and Predominance of Genotype 4 in Rural Gabon. Journal of Medical Virology, 80, 1581-1587. https://doi.org/10.1002/jmv.21252

[35] Saddadi, F., Attari, F., Najafi, I., Gangi, M.R., Hakemi, M. and Amini, M. (2010) Renal Involvement in Patients with Hepatitis C Virus Infection. The Iranian Journal of Kidney Diseases, 4, 123-127.

[36] Huang, J.-F., Chuang, W.-L., Dai, C.-Y., Ho, C.-K., Hwang, S.-J., Chen, S.-C., et al. (2006) Viral Hepatitis and Proteinuria in an Area Endemic for Hepatitis B and C Infections: Another Chain of Link? Journal of Internal Medicine, 260, 255-262. https://doi.org/10.1111/j.1365-2796.2006.01686.x

[37] Ozkok, A. and Yildiz, A. (2014) Hepatitis C Virus Associated Glomerulopathies. World Journal of Gastroenterology, 20, 7544-7554. https://doi.org/10.3748/wjg.v20.i24.7544

[38] Perico, N., Cattaneo, D., Bikbov, B. and Remuzzi, G. (2009) Hepatitis C Infection 
and Chronic Renal Diseases. Clinical Journal of the American Society of Nephrology, 4, 207-220. https://doi.org/10.2215/CJN.03710708

[39] Sansonno, D., Lauletta, G., Montrone, M., Grandaliano, G., Schena, F.P. and Dammacco, F. (2005) Hepatitis C Virus RNA and Core Protein in Kidney Glomerular and Tubular Structures Isolated with Laser Capture Microdissection. Clinical \& EXperimental Immunology, 140, 498-506. https://doi.org/10.1111/j.1365-2249.2005.02778.x

[40] Iseki, K., Ikemiya, Y., Iseki, C. and Takishita, S. (2003) Proteinuria and the Risk of Developing End-Stage Renal Disease. Kidney International, 63, 1468-1474. https://doi.org/10.1046/j.1523-1755.2003.00868.x

[41] Association Médicale Mondiale (2013) Déclaration d'Helsinki de l’Association Médicale Mondiale: Principes éthiques applicables aux recherches médicales sur des sujets humains.

https://www.wma.net/fr/policies-post/declaration-dhelsinki-de-lamm-principes-eth iques-applicables-a-la-recherche-medicale-impliquant-des-etres-humains

[42] World Health Organization, Council for International Organizations of Medical Sciences (2017) International Ethical Guidelines for Health-Related Research Involving Humans. CIOMS, Geneva. 


\section{List of Abbreviations}

ACR: Albuminuria/creatinuria ratio

BMI: Body mass index

CHVC: Chronic viral Hepatitis C

CKD: Chronic kidney disease

CKD-EPI: Chronic Kidney Disease Epidemiology Collaboration

eGFR: estimated glomerular filtration rate

HCV: Hepatitis C virus

MDRD: Modification of Diet in Renal Disease

MHD: Maintenance hemodialysis

MPGN: Membranoproliferative glomerulonephritis

SSA: sub-Saharan Africa

SPSS: Statistical Package for Social Sciences

USA: United States of America 